\title{
PEMBUATAN DAN KARAKTERISASI NANOPARTIKEL EKSTRAK ETANOL TEMU KUNCI (Boesenbergia pandurata) PADA BERBAGAI VARIASI KOMPOSISI KITOSAN
}

\section{THE PREPARATION AND CHARACTERIZATION OF FINGERROOT (Boesenbergia pandurata) ETANOL EXTRACT NANOPARTICLES WITH VARIOUS CITOSAN COMPOTITION}

\author{
Dessy Kurniasari, Sri Atun* \\ Jurusan Pendidikan Kimia, FMIPA UniversitasNegeri Yogyakarta \\ *email: atun_1210@yahoo.com
}

Diterima 10 Februari 2017, disetujui 10 April 2017

\begin{abstract}
Abstrak
Penelitian ini bertujuan membuat dan mengetahui karakteristik nanopartikel dari ekstrak etanol temu kunci (Boesenbergia pandurata). Pembuatan ekstrak temu kunci menggunakan metode maserasi menggunakan etanol teknis $96 \%$ dilanjutkan evaporasi hingga terbentuk ekstrak kental. Koloid nanopartikel dibuat dengan mencampurkan ekstrak temu kunci dalam etanol p.a, akuades, larutan kitosan dalam asam asetat glasial, dan larutan NaTPP. Ada 9 variasi komposisi antara larutan kitosan dan NaTPP. Padatan dalam koloid nanopartikel dipisahkan dengan cara sentrifugasi. Endapan yang didapatkan disimpan dalam freezer. Koloid nanopartikel yang terbentuk dikarakterisasi menggunakan Particle Size Analyzer (PSA) dan Zeta Sizer untuk mengetahui ukuran partikel dan nilai zeta potensial. Padatan yang didapatkan dari proses sentrifugasi selanjutnya dikarakterisasi menggunakan Scanning Electron Microscopy (SEM) untuk mengetahui kondisi morfologi padatan tersebut. Karakterisasi dengan KLT pada padatan yang didapatkan bertujuan mengetahui kesamaan kandungan senyawa antara ekstrak etanol temu kunci dan ekstrak etanol temu kunci dalam sediaan berukuran nano. Koloid nanopartikel yang telah dibuat berwarna kuning dan disentrifugasi terbentuk padatan berwarna kuning kecokelatan. Karakterisasi menggunakan PSA menunjukkan ukuran partikel pada rentang $389-877 \mathrm{~nm}$ sebanyak $98,1 \%$ pada rasio konsentrasi kitosan dan NaTPP $=(8: 1)$. Nilai rerata zeta potensial adalah $41,87 \mathrm{mV}$. Hasil foto SEM menunjukkan morfologi partikel yang memiliki permukaan yang tidak rata. Rf keenam sampel menunjukkan hasil bahwa senyawa yang terkandung dalam ekstrak etanol temu kunci maupun ekstrak etanol temu kunci dalam sediaan nanopartikel adalah sama.
\end{abstract}

Kata Kunci : kitosan, NaTPP, ekstrak etanol temu kunci, KLT, SEM, PSA, zeta sizer

\begin{abstract}
This research aimed for creating and determining characteristic of fingerroot (Boesenbergia pandurata) nanoparticles. Preparation of fingerroot ethanol extract was performed by maceration method with etanol $96 \%$ followed by evaporation to form viscous extract. Colloidal nanoparticles were made by mixing the viscous extract of fingerroot with ethanol, aquadest, chitosan solution in acetat glacial acid, and STPP. There were 9 variations of chitosan and STPP compotition ratio. Colloidal nanoparticles were centrifuged to separate preciptate of fingerroot nanoparticles. Then, the precipitate of fingerroot was kept in freezer. Characterization nanoparticles size and zeta potential of fingerroot nanoparticles was performed using Particle Size Analyzer (PSA) and Zeta Sizer. Morfologi of preciptated nanoparticles characterized using Scanning Electron Microscopy (SEM). Characterization of preciptate nanoparticles using TLC for determining the similarity of compounds fingerroot etanol extract and etanol extract nanoparticles. Colloidal nanoparticles that have been prepared form yellow color and after sentrifugation, it form solid yellow-brown. Characterization using PSA showed the nanoparticle size by $389-877 \mathrm{~nm} 98,1 \%$ in the ratio concentration of chitosan and STPP $=8: 1$. The average of zeta potential value was $41,87 \mathrm{mV}$. Outcome from using SEM showed the morfologi of preciptated particle. The $\mathrm{Rf}$ of six sample showed that compound in extract ethanol of fingerroot and nanoparticle extract ethanol of fingerroot was the same.
\end{abstract}

Keywords : chitosan, STPP, fingerroot extract, nanoparticles, TLC, SEM, PSA, zeta sizer 


\section{Pendahuluan}

Indonesia merupakan salah satu negara yang memiliki keanekaragaman hayati yang cukup melimpah. Salah satu kekayaan hayati yang ada di Indonesia adalah tanaman obatnya yang memiliki banyak manfaat bagi kesehatan manusia.

Boesenbergia ,pandurata Roxb. (Zingiberaceae), lebih dikenal dengan nama "temu kunci", merupakan salah satu tanaman obat yang ada di Indonesia. Rimpang dari tanaman ini secara tradisional digunakan untuk pengobatan beberapa penyakit. Rimpang temu kunci mengandung essential oils dan beberapa senyawa flavonoid yang berguna bagi pengobatan sebagai antifungal, antibacterial, antioksidan, dll. Salah satu senyawa flavonoid dalam tanaman ini yaitu panduratin, memiliki kemampuan yang cukup kuat sebagai antifungal, antibakteri, anti-inflammatory, dan antikanker[1].

Efisiensi dari penggunaan obat selalu terhambat oleh kemampuan obat itu sendiri dalam mencapai tempat aksinya. Dalam banyak kasus (ukuran normal), hanya sedikit jumlah obat yang dapat mencapai target tempat aksi, sementara sebagian besar dari obat didistribusikan keseluruh tubuh sesuai dengan kandungan physicochemical dan biochemicalnya [2].

Nanopartikel merupakan partikel koloid padat dengan diameter 1-1000 $\mathrm{nm}$ [2]. Mengandung makromolekuler material dan dapat digunakan untuk pengobatan sebagai pembawa obat yang senyawa aktifnya telah terlarut, terjerat, dan encapsulated[2].

Kitosan adalah polisakarida yang banyak terdapat di alam setelah selulosa. Kitosan merupakan suatu senyawa poli (Namino-2-deoksi- $\beta$-D-glukopiranosa) atau glukosamin hasil deasetilasi kitin/poli ( $\mathrm{N}$-asetil2-amino-2-deoksi- $\beta$-D-glukopiranosa). Kitosan mempunyai sifat spesifik yaitu adanya sifat bioaktif, biokompatibel, pengkelat, antibakteri dan dan dapat terbiodegrasi [3].

Namun demikian, kitosan hanya larut dalam media air dengan keberadaan sedikit asam dan sifat-sifatnya kurang baik untuk aplikasi biomedis [4]. Salah satu pemanfaatan kitosan dalam sistem biomedis atau biologis adalah pada sistem penghantaran obat dan pelepasan obat [5]. Pada sistem ini pelepasan obat dengan kitosan memiliki keterbatasan karena kitosan cepat sekali menyerap air dan memiliki derajat swelling yang tinggi dalam lingkungan berair, hal tersebut akan menyebabkan pelepasan obat terjadi lebih cepat [6].

Penelitian yang dilakukan Bhumkar dan Varsha mempelajari pembuatan partikel kitosan ter-crosslink dengan TPP dengan metode ionotrophic gelation. Kitosan yang diikat silang secara ionik menunjukkan derajat swelling yang rendah. Kitosan yang terikat silang ini juga mudah diatur sesuai dengan fungsi yangdiinginkan, seperti hidrofilisitas, kerapatan, dan kristalinitas [7]. Metode gelasi ionik juga berhasil digunakan dalam pembuatan nanopartikel fraksi kloroform Kaempferia rotunda dengan kitosan dan Na-TPP. Hasil pengukuran nanopartikel adalah antara 172 sampai $877 \mathrm{~nm}$ dengan nilai zeta potensial antara $+28,06$ sampai $+38,03 \mathrm{mV}[8]$.

Berdasarkan uraian sebelumnya, manfaat baik yang terkandung dalam temu kunci dapat ditingkatkan dengan cara mengubahnya menjadi bentuk nanopartikel. Mencari perbandingan yang tepat antara kitosan dan Na-TPP dalam pembuatan nanopartikel temu kunci merupakan tantangan dalam penelitian ini.

\section{Metode Penelitian}

\begin{abstract}
Alat
PSA (Particle Size Analyzer) HORIBA LB-550 (IK 03 TP 016), SEM (Scanning Elevtron Microscopy), Zeta Sizer Nano series Malvem, satu set evaporator buchii 190, gelas beker, corong kaca, erlenmeyer, gelas ukur, pipet volum, kertas saring, tissue, spatulla, magnetic stirrer, satu set alat sentriuge, dan satu set alat KLT (Kromatografi Lapis Tipis).
\end{abstract}

\section{Bahan}

Rimpang temu kunci (Boesenbergia pandurata), kitosan, NaTPP, etanol teknis $96 \%$, etanol p.a., asam asetat glasial, akuades, kloroform.

\section{Prosedur Kerja}

Tahap Pengumpulan dan Penyiapan Sampel 
Sampel berupa rimpang temu kunci (Boesenbergia pandurata) diperoleh dari Pasar Beringharjo Yogyakarta, DIY, Indonesia. Sebelum diteliti lebih lanjut, sampel diidentifikasi di Laboratorium Sistematika Tumbuhan, Fakultas Biologi, Universitas Gadjah Mada, Yogyakarta. Selanjutnya, sampel dibersihkan, dipotong-potong lalu dikeringkan di udara terbuka dengan bantuan sinar matahari. Sampel yang telah kering kemudian digiling sampai menjadi serbuk halus yang siap diekstraksi.

\section{Ekstraksi dengan Maserasi}

Serbuk rimpang temu kunci dimaserasi menggunakan etanol teknis $96 \%$ selama 24 jam berulang-ulang sebanyak 3 kali pada suhu kamar. Ekstrak etanol temu kunci diperoleh dengan cara penyaringanmenggunakan kertas saring. Ekstrak etanol yang diperoleh diuapkan pelarutnya menggunakan evaporator buchii menghasilkan ekstrak etanol kental.

\section{Pembuatan Nanopartikel Ekstrak Etanol Temu} Kunci

Ekstrak etanol kental dari temu kunci seberat 1 gram, dilarutkan dalam $35 \mathrm{~mL}$ etanol p.a, ditambahkan $15 \mathrm{~mL}$ akuades dalam gelas beker $2000 \mathrm{~mL}$. Kitosan dalam $100 \mathrm{~mL}$ asam asetat glasial $1 \%$ dan larutan NaTPP sebanyak $350 \mathrm{~mL}$. Ada 9 variasi komposisi perbandingan kitosan dan NaTPP pada larutan yang dibuat yaitu adalah (5:1); (10:1); (15:1); (20:1); $(3,3: 1) ; \quad(8: 1) ; \quad$ (9:1); (11:1); dan (12:1). Pengadukan menggunakan magnetic stirrer selama \pm 2 jam. Koloid nanopartikel kitosanNaTPP temu kunci kemudian dipisahkan dengan cara sentrifugasi. Padatan yang diperoleh kemudian dimasukkan dalam freezer $\left( \pm-4^{\circ} \mathrm{C}\right)$ selama \pm 2 hari. Penyimpanan dipindahkan dalam lemari es $\left( \pm 3^{\circ} \mathrm{C}\right)$ sampai kering. Koloid nanopartikel yang dihasilkan dikarakterisasi menggunakan PSA (Particle Size Analyzer) dan Zeta Sizer untuk mengetahui ukuran partikel dan nilai zeta potensialnya. Padatan yang terbentuk dikarakterisasi menggunakan SEM (Scanning Electron Microscopy) untuk mengetahui bentuk morfologi dalam bentuk padatannya. Karakterisasi selanjutnya menggunakan KLT (Kromatografi Lapis Tipis) untuk mengetahui kesamaan senyawa temu kunci dalamekstrak etanol maupun dalam sediaan nanopartikel ekstrak etanol temu kunci.

\section{Hasil dan Pembahasan}

Ekstrak kental hasil ekstraksi seberat 47,621 gram dari $3 \mathrm{~kg}$ serbuk kering rimpang temu kunci.

Pembuatan nanopartikel berupa koloid menghasilkan warna kuning dan padatan nanopartikel hasil sentrifuge berwarna cokelat kekuningan. Karakterisasi menggunakan PSA menunjukkan sampel dengan ukuran nano $(<1000 \mathrm{~nm})$ yang paling besar adalah sampel dengan rasio kitosan dan NaTPP (8:1) dengan kitosan $0,08 \%$ dan NaTPP 0,01\%. Ukuran persen (\%) nanopartikel sebanyak 98,1\% adalah 389-877 $\mathrm{nm}$ dan ukuran mikropartikel sebanyak $1,9 \%$ adalah $1005 \mathrm{~nm}$. Nilai zeta potensial rata-rata adalah $41,87 \mathrm{mV}$. Sehingga, komposisi kitosan dan NaTPP (8:1) merupakan komposisi yang optimum untuk menghasilkan partikel berukuran nano yang optimal. Hasil identifikasi menggunakan KLT menunjukkan hasil yang baik dengan nilai Rf yang hampir sama, Rf keenam sampel yang diidentifikasi menunjukkan nilai yang hampir sama, yaitu $\mathrm{Rf}$ $\mathrm{A}=0,25$ dan 0,$60 ; \operatorname{Rf} \mathrm{B}=0,23$ dan 0,$58 ; \operatorname{Rf} \mathrm{C}$ $=0,22$ dan 0,57; Rf $\mathrm{D}=0,22$ dan 0,57; Rf $\mathrm{E}$ 0,23 dan 0,58 ; $\operatorname{Rf} F=0,30$ dan 0,63. Dengan keterangan kode $\mathrm{A}$ adalah sampel ekstrak etanol temu kunci dan B-F adalah sampel G s.d K. Kromatogram dapat dilihat pada Gambar 1.

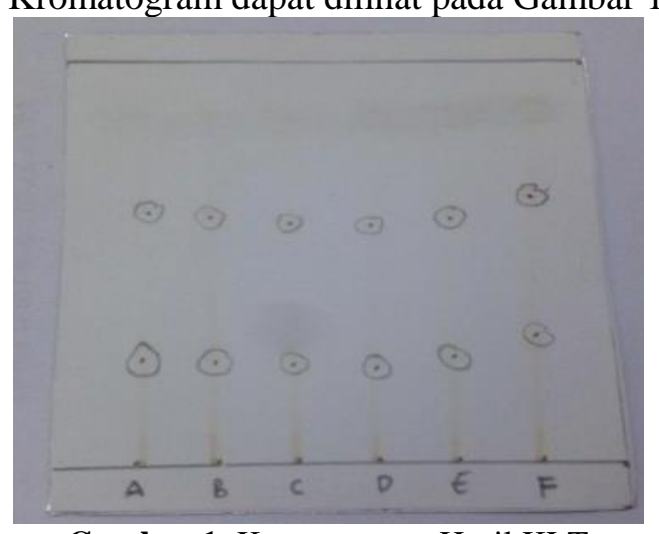

Gambar 1. Kromatogram Hasil KLT

Penggunaan kitosan pada penelitian ini dikarenakan kitosan merupakan polimer yang memiliki sifat bioaktif, biokompatibel, pengkelat, antibakteri, dan dapat terbiodegrasi. Akan tetapi kitosan cepat sekali menyerap air dan memiliki derajat swelling yang tinggi dalam lingkungan berair, sehingga pada aplikasi biologis dan medis sebagai sistem penghantaran dan pelepasan obat kurang 
menguntungkan. Oleh karena itu penambahan NaTPP perlu dilakukan untuk menghasilkan turunan kitosan dengan peningkatan biokompatibilitas dan menurunkan derajat swelling.

Penggunaan NaTPP sebagai agen crosslinkerdengan dosis yang rendah bertujuan agar tidak terjadi ikatan yang terlalu banyak antara polianion TPP dengan gugus amina pada kitosan. Metode ini disebut metode gelasi ionik dengan menggunakan pasangan polimer kitosan dan NaTPP. Mekanisme terbentuknya nanopartikel kitosan terbentuk berdasarkan interaksi elektostatic antara gugus amina dari kitosan dan gugus negatif dari polianion seperti tripolifosfat. Metode gelasi ionik merupakan metode yang mudah dilakukan dibandingkan dengan metode-metode yang lainnya. Kitosan yang terlarut dalam asam asetat kemudian ditambahkan dengan polianion atau anionik polimer, secara spontan akan terbentuk nanopartikel dengan pengadukan menggunakan magnetic stirrerpada temperatur ruangan. Ukuran dan struktur permukaan partikel dapat dimodifikasi dengan memvariasikan rasio kitosan dan NaTPP [2]. Hasil pengukuran menggunakan PSA (berupa ukuran partikel) dan nilai zeta potensial seluruh variasi sampel dapat dilihat pada Tabel 1. Pada penggunaan persen (\%) NaTPP yang tinggi dengan persen (\%) penggunaan kitosan yang sama akan menghasilkan partikel berukuran mikro lebih banyak.

Sentrifugasi dari koloid nanopartikel menghasilkan padatan nanopartikel kering berwarna cokelat kekuningan seperti ditunjukkan pada Gambar 2.

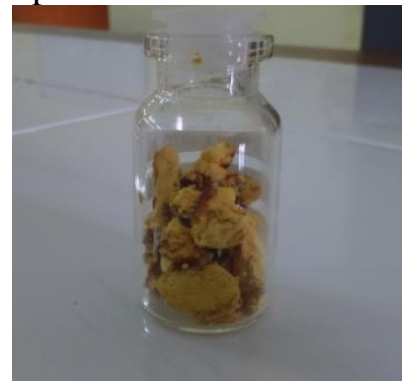

Gambar 2. Endapan Kering Nanopartikel

Analisis menggunakan SEM pada sampel yang memiliki persen $(\%)$ nanopartikel tinggi menunjukkan bentuk permukaan partikel yang menyerupai stalaktit dan stalakmit pada goa, Gambar 3(a).

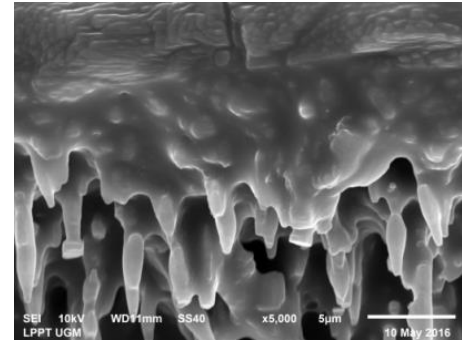

(a)

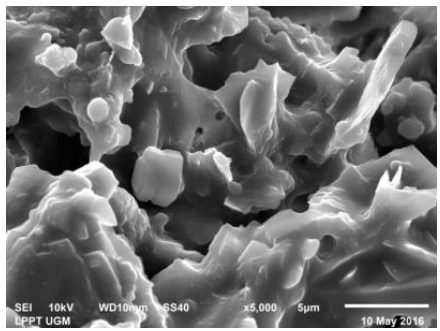

(b)

Gambar 3. Hasil SEM Sampel G dengan perbesaran 5000x tampak samping (a) dan tampak atas (b)

\section{Simpulan}

Nanopartikel ekstrak etanol temu kunci (Boesenbergia pandurata) dengan kitosan dan NaTPP (Natrium tripolifosfat) pada berbagai variasi komposisi berhasil dibuat dengan 11 variasi komposisi. Komposisi kitosan dan NaTPP untuk membentuk nanopartikel yang paling optimal adalah komposisi pada sampel $\mathrm{G}$ dengan rasio konsentrasi (8:1) dengan konsentrasi kitosan dalam asam asetat glasial $0,08 \%$ dan NaTPP $0,01 \%$. Hasil karakterisasi komposisi yang optimal menggunakan PSA (Particle Size Analyzer) adalah partikel berukuran nano pada rentang $389-877 \mathrm{~nm}$ sebanyak $98,1 \%$. Karakterisasi menggunakan Zeta Sizer menghasilkan nilai rerata zeta potensial $41,87 \mathrm{mV}$, karakterisasi menggunakan instrumen SEM menunjukkan morfologi permukaan ekstrak etanol temu kunci dalam bentuk nanopartikel yakni permukaan yang tidak rata, sedangkan hasil karakterisasi menggunakan KLT (Kromatografi Lapis Tipis) menunjukkan nilai $\mathrm{Rf}$ yang kurang lebih sama untuk keenam sampel, dengan kata lain kandungan senyawa dalam temu kunci tetap sama, baik dalam bentuk ekstrak etanol maupun sediaan nanopartikelnya. Hasil pengukuran persen (\%) nanopartikel dan nilai zeta potensial secara lengkap disajikan pada Tabel 1. 
Tabel 1. Hasil pengukuran Ukuran Partikel dan Nilai Zeta Potensial

\begin{tabular}{cccccccccc}
\hline $\begin{array}{l}\text { Sam } \\
\text { Pel }\end{array}$ & $\begin{array}{c}\text { Kitosan } \\
(\%)\end{array}$ & $\begin{array}{c}\text { NaTPP } \\
(\%)\end{array}$ & $\begin{array}{c}\text { Nano } \\
\text { partikel }\end{array}$ & $\begin{array}{c}\text { Ukuran } \\
\text { nano } \\
(\mathrm{nm})\end{array}$ & $\begin{array}{c}\text { \% Mikro } \\
\text { partikel }\end{array}$ & $\begin{array}{c}\text { Ukuran } \\
\text { mikro } \\
(\mathrm{nm})\end{array}$ & $\begin{array}{c}\text { Nilai } \\
\text { Zeta } \\
\text { Potensial } \\
(\mathrm{Mv})\end{array}$ & Berat & Warna \\
\hline $\mathrm{A}$ & 0,10 & 0,02 & 1,3 & 877 & 98,7 & $1005-1510$ & - & 0,3344 & Cokelat \\
\hline $\mathrm{B}$ & 0,20 & 0,02 & 68.7 & $510-877$ & 31,3 & $1005-1510$ & 26,83 & 0,4444 & Cokelat \\
\hline $\mathrm{C}$ & 0,30 & 0,02 & 0,0 & & 100,0 & $1005-1729$ & - & 0,3948 & Cokelat \\
\hline $\mathrm{D}$ & 0,40 & 0,02 & 1,0 & $766-877$ & 99,0 & $1005-2269$ & 14,40 & 0,5235 & Cokelat \\
\hline $\mathrm{E}$ & 0,10 & 0,01 & 75,8 & $389-877$ & 24,2 & $1005-1151$ & 32,77 & 0,4401 & Cokelat \\
\hline $\mathrm{F}$ & 0.10 & 0,03 & 0,0 & & 100,0 & $1005-1981$ & - & 0,687 & Cokelat \\
\hline $\mathrm{G}$ & 0.08 & 0,01 & 98,1 & $389-877$ & 1,9 & 1005 & 41,87 & 0,501 & Cokelat \\
\hline $\mathrm{H}$ & 0,09 & 0,01 & 70,1 & $296-877$ & 29,9 & $1005-1729$ & - & 0,380 & Cokelat \\
\hline $\mathrm{I}$ & 0,10 & 0,01 & 45,7 & $339-877$ & 54,3 & $1005-1729$ & - & 0,414 & Cokelat \\
\hline J & 0,11 & 0,01 & 19,0 & $766-877$ & 81,0 & $1005-1151$ & - & 0,478 & Cokelat \\
\hline K & 0,12 & 0,01 & 53,7 & $339-877$ & 46,3 & $1005-1510$ & - & 0,413 & Cokelat \\
\hline
\end{tabular}

\section{Ucapan Terima Kasih}

Penulis mengucapkan terimakasih kepada Prof. Dr. Sri Atun selaku Pembimbing Utama dalam penelitian yang saya lakukan.

\section{Pustaka}

[1] Agus Chahyadi, dkk. (2014). Boesenbergia pandurata Roxb., An Indonesian Medical Plant: Phytochemistry, Biological Activity, Plant Biotechnology. Procedia Chemistry, 1314.

[2] Tiyaboonchai, Waree,(2013).Chitosan Nanoparticles: A Promising System for Drug Delivery. Naresuan University Journal.11,5166.

[3] L.O.A.N. Ramadhan, dkk. (2010). Deasetilasi Kitin Bertahap dan Pengaruhnya terhadap
Derajat Deasetilasi serta massa molekul kitosan. Jurnal Kimia Indonesia, 5, 7-21.

[4] ZhangM, Li XH, Gong YD, Zhao NM \& Zhang XF.2002. Properties and biocompatibility of chitosan films modified by blending with PEG. Biomaterials, 23, 26412648.

[5] Stamatialis DF, Papenburg BJ, Giron'es M, Saiful S, Bettahalli SNM, Schmitmeier S \& Wessling M.(2008). Medical applications of members: Drug delivery, artificial organ and tissue engineering. J Membrane Sci, 308, 1-34.

[6] M. Alaudin dan N. Widiarti. (2014). Sintesis dan Modifikasi Lapis Tipis KitosanTripolifosfat. Jurnal MIPA. 1, 46-52.

[7] Bhumkar DR \& Varsha BP.(2006). Studies on effect of $\mathrm{pH}$ on crosslinking of chitosan with sodium tripolyphosphate:a technical note. AAPS Pharm SCi Tech, 7, 1-6. 